\title{
Degradation of oxytetracycline in honey as measured by fluorescence and liquid chromatographic assays
}

\author{
RJ Argauer *, WA Moats \\ Agricultural Research Service, USDA, Bee Research Laboratory, Beltsville, MD 20705, USA
}

(Received 4 October 1990; accepted 31 January 1991)

\begin{abstract}
Summary - Federal regulations in many countries do not permit residues of oxytetracycline (OTC) in marketable honey. At or near the low limit of detection by fluorescence assay we have found that unforeseen nectar sources could lead to false positive readings. In an effort to maximize sensitivity and increase confidence in detecting trace amounts of OTC in samples of honey, a rapid HPLC isocratic method has been developed that uses a poly(styrene-60\% divinylbenzene) column (Polymer Labs, PLRP-S). Honey is diluted 1:4 with $0.1 \mathrm{~N}$ hydrochloric acid and a 200- $\mu$ l aliquot of the diluted honey sample is injected. The utility of the method was demonstrated by medicating research colonies of the honey bee, Apis mellifera, with OTC and analyzing the honey stored by the foraging bees. Both fluorescence assay and HPLC methods proved suitable for determining the stability of oxytetracycline in aqueous solutions and in honey stored at various temperatures. Between $0.5-50 \mathrm{ppm}$ of OTC in research samples of honey can be determined within 15 min by the new HPLC method described.
\end{abstract}

honey / residue / antibiotic / HPLC / fluoresence

\section{INTRODUCTION}

Tetracycline antibiotics are used in many countries as veterinary medicines and feed additives. Some of the major uses, risks, and benefits, and regulatory problems associated with agricultural uses of antibiotics have been the subject of critical reviews (Moats, 1986a). Oxytetracycline (OTC) is useful for the control of diseases in fish supplied by fish farms (aquaculture, cultivated fish) and for the prevention and control of European foulbrood and American foulbrood diseases of the honey bee, Apis mellifera. Terramycin (oxytetracycline hydrochloride) is the only drug registered in the United States for the feeding of medicated sugar syrups and powdered sugar dusts to honey bee colonies to aid in the prevention and control of American and European foulbrood diseases. No amount of oxytetracycline residues is permitted in honey marketed for human consumption in the United States.

Fluorescence assay of OTC in honey has been used to evaluate drug application systems used by the apiculturist (Gilliam and Argauer, 1981; Argauer, 1986). HPLC methodologies for the determination of tetracyclines are being continually

\footnotetext{
* Correspondence and reprints
} 
improved to increase selectivity and sensitivity. Ashworth (1985), Moats (1986b), and Ikai et al (1987) describe some of the difficulties encountered in the determination of tetracyclines by HPLC in blood, urine, and tissues of food-producing animals. Sporns et al (1986) used a modified version of the HPLC procedure suggested by Knoy and Jurand (1979) to analyze for OTC residues in honey in which OTC residues were concentrated through organic solvent extraction. Juergens (1981) determined tetracyclines in honey by HPLC on an RP-8 column. Takeba et al (1984) and Oka et al (1987) determined tetracyclines in honey using reversed phase and ionexchange cartridges as a clean-up system prior to HPLC on an RP-8 column. We compare the HPLC results obtained using direct $200-\mu \mathrm{l}$ injections of diluted honey samples with results obtained using the fluorescence assay technique which uses a lengthy solvent extraction technique as described by us previously (Gilliam and Argauer, 1981). Our objectives were to develop a rapid chromatographic method for the determination of OTC in honey and to determine the rate of degradation of OTC in honey removed from medicated colonies.

\section{MATERIALS AND METHODS}

\section{Honey bee colony medication}

A honey bee colony was treated with a medicated dust using terramycin medicated powder mixed with sugar $(3.8 \mathrm{~g}$ of animal soluble powder terramycin containing $200 \mathrm{mg}$ of OTC activity mixed with $29 \mathrm{~g}$ of powdered sugar) according to label instructions. The bees were free to forage. We next purposely deviated from the precautions given on the label for harvesting marketable honey in order to produce incurred residues of OTC in the stored honey. Five $d$ after treatment, frames filled with uncapped hon- ey(nectar) were removed from 1 hive and the honey strained through cheese-cloth. Five-g portions of the strained honey were weighed into 40 or more small beakers. The beakers were incubated at $34^{\circ} \mathrm{C}$, and at specified time-periods, removed and stored in a freezer at $-10^{\circ} \mathrm{C}$ to await analysis.

\section{Instrumentation}

For the fluorescence assay method, a PerkinElmer Model MPF-2A spectrofluorometer was used with a xenon power supply. For the HPLC assay method, a Varian LC Model 5000 liquid chromatograph with a Varian variable wavelength detector set at $355 \mathrm{~nm}$, and a Valco automatic loop injector with a 200- $\mu$ l loop was used with a 100 A PLRP-S, 5 micron, $15 \mathrm{~cm} \times 4.6 \mathrm{~mm}$ column (Polymer Laboratories Ltd). The pump was operated isocratically at a flow rate of $1 \mathrm{ml} /$ $\mathrm{min}$. The mobile phase was a mixture of $0.01 \mathrm{M}$ phosphoric acid-acetonitrile-methanol 81:14:5. After use, the system was flushed for $5 \mathrm{~min}$ with water and then with a 1:1 water-acetonitrile for $10 \mathrm{~min}$ at the end of the work day.

\section{Fluorescence assay method}

Five $\mathrm{g}$ of honey were weighed into a $125-\mathrm{ml}$ separatory funnel and diluted with $10 \mathrm{ml}$ of a solution of $0.3 \mathrm{M}$ trichloroacetic acid and $1 \mathrm{M}$ sodium chloride. Next $25 \mathrm{ml}$ of an ethyl acetate solution (500 $\mathrm{ml}$ ethyl acetate and $5.25 \mathrm{ml}$ ethyl acetoacetate) were added, and the funnel was shaken for $3 \mathrm{~min}$ in order to extract the OTC. The lower layer was discarded. To the upper layer still remaining in the separatory funnel was added 10 $\mathrm{ml}$ of a solution (2 $\mathrm{M}$ ammonium hydroxide and $1 \mathrm{M}$ sodium chloride) and $0.5 \mathrm{ml}$ of $0.05 \mathrm{M}$ calcium chloride. This causes the formation of a calcium ion-OTC complex that will remain in the organic layer, while potential interferences such as co-extracted phenols and acids are transferred into the aqueous lower layer. The funnel was shaken for $2 \mathrm{~min}$, a portion of the upper layer decanted into a cuvette, and the fluorescence intensity compared at an excitation wavelength of $390 \mathrm{~nm}$ and an emission wavelength of $520 \mathrm{~nm}$ with standards prepared similarly. The 
fluorescence standards were prepared by adding $0,10,50,100$, and $200 \mu \mathrm{l}$ of a stock solution containing $100 \mu \mathrm{l} / \mathrm{ml}$ oxytetracycline $\cdot 2 \mathrm{H}_{2} \mathrm{O}$ (MW 496) in $0.1 \mathrm{~N}$ hydrochloric acid to $10 \mathrm{ml}$ of the sodium chloride-trichloroacetic acid solution in $125 \mathrm{ml}$ separatory funnels and proceeding as above.

\section{HPLC assay method}

Five $g$ of honey were weighed into a small beaker and diluted with $25 \mathrm{ml}$ of $0.1 \mathrm{~N}$ hydrochloric acid to a final vol of $\approx 28 \mathrm{ml}$. A $200-\mu \mathrm{l}$ aliquot was injected into the liquid chromatograph and the chromatograms obtained compared with $200-\mu l$ injections of a series of standard solutions of oxytetracycline $(0.2,0.5,1.0$, and 2.0 $\mu \mathrm{g} / \mathrm{ml}$ in $0.1 \mathrm{~N}$ hydrochloric acid). Various samples of honey were also weighed directly into appropriate volumetric flasks and diluted.

\section{RESULTS AND DISCUSSION}

The simplicity inherent in the HPLC assay method is clearly evident from the description in the Materials and Methods section. Chromatograms in figure 1 were obtained for an OTC standard and for honey that contains OTC at levels of 15 and $5 \mathrm{ppm}$. We were consistently able to obtain reproducible results by simply diluting the honey samples 1:4 with $0.1 \mathrm{~N} \mathrm{HCl}$ and injecting $200-\mu$ l aliquots. Unfortified honey samples (background controls) yielded similar chromatograms approaching the chromatographic baseline at the retention time for OTC of $6.1 \mathrm{~min}$. Recoveries of OTC from OTC-fortified honey samples were nearly $100 \%$ using the HPLC assay method described. However, recoveries using the fluorescence assay method described were between $80-90 \%$. Data presented in figure 2 compare the results obtained for honey samples in which OTC is incorporated into the honey by the bee (incurred residue). The data points plotted above the line were obtained by the HPLC assay method. Data points below were obtained by fluorescence assay. The half-life of OTC in honey (uncapped nectar) removed from the bee colony and incubated at a brood nest temperature of $34{ }^{\circ} \mathrm{C}$ was found to be $\approx 12 \mathrm{~d}$ as calculated from the data in figure 2. This can be compared with a half-life of $\approx 14 \mathrm{~d}$ at $30^{\circ} \mathrm{C}$ for OTC in honey fortified with an OTC standard dissolved in methanol (Sporns et al, 1986) and a half-life of $\approx 2-4 d$ when the honey remains undisturbed in the cells of the comb within the active bee colony (Gilliam and Argauer, 1981). The differences observed in the stability of OTC in honey may be attributed to changes in enzymatic activity of the honey in the 3 different environments. Recommendations for the proper use of terramycin are found on the label and have been based principally upon data obtained by microbiological assay that depends on the inhibition of growth of an indicator bacterium by OTC (Rousseau and Tabarly, 1962; Corner and Gochnauer, 1971; Gochnauer and Bland, 1974). Our results support these earlier observations based on microbiological assay that serve as a basis for the proper use of the medication. The warning printed on the label clearly states that medicated treatments should be terminated at least 4 wk before the main honey flow begins. In addition, all honey and syrup stored during medication periods in combs for surplus honey should be removed following final medication and must not be used for human consumption.

\section{Visual observation of catalyzed degradation of OTC under basic chromatographic conditions}

The advantage of the PLRP-S column is that it may be used with mobile phases throughout a wide $\mathrm{pH}$ range and thus al- 


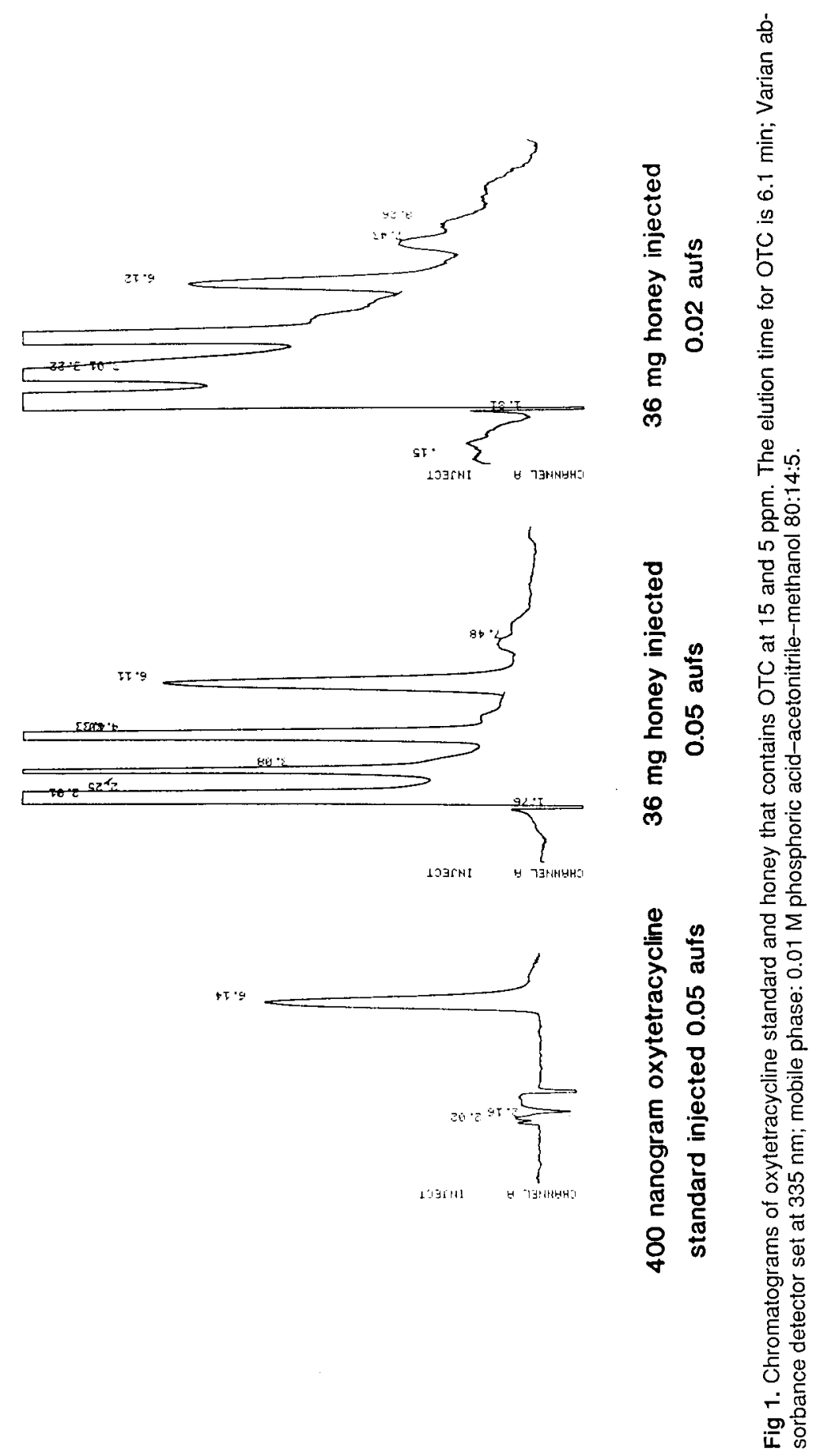




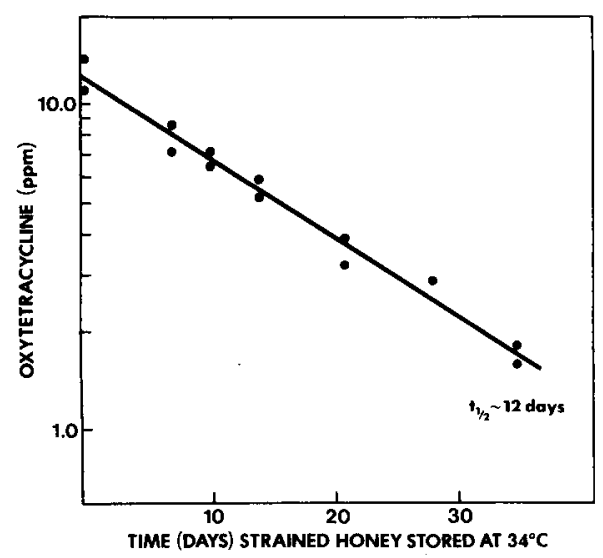

Fig 2. Degradation of oxytetracycline in nectar (uncapped honey) after removal from a medicated colony. HPLC assay data points plotted above line; fluorescence assay data plotted below line.

lows the use of an alkaline mobile phase, in contrast to silica-based columns where silica dissolves at a high $\mathrm{pH}$. We therefore attempted to further increase sensitivity and selectivity by developing a second rapid HPLC method based on monitoring the natural fluorescence produced by OTC in basic solutions. We had no success. In order to explain the very poor recoveries found when basic solutions were used as the mobile phase, we pipetted standard acid solutions of OTC into a glass column that contained XAD-2 (30/60 mesh) resin. We next attempted to elute the adsorbed OTC with mobile phases that contained diand tri-sodium phosphates. In a darkened laboratory with the use of a longwavelength ultraviolet lamp we were able to readily observe the rapid degradation of OTC adsorbed onto the XAD-2 (30/60 mesh) column by visually fallowing the rapid decline in fluorescence of the absarbed OTC in the presence of these mabile phases. We made no attempt to adjust $\mathrm{pH}$ post-column in order to monitor the induced fluorescence after chromatographic separation with an acidified mobile phase.

\section{CONCLUSION}

The HPLC method is simplier to use and gives better recoveries than the fluorescence assay method. As was the case with microbiological and fluorescence assay methods, the detection limit of HPLC methodologies is ultimately governed by interfering peaks that may become more troublesome at or near the limit of detection. We have not obtained the background chromatograms for the thousands of varieties of honeys that are produced from the various types of nectar available to the honey bee throughout the world. Between 0.5 and $50 \mathrm{ppm}$ of OTC in research samples of honey can be determined within 15 min by the new HPLC method described. We expect the HPLC method to be suitable generally for all kinds of honey but we have no way of telling whether some types of honey may contain interferences that could reduce sensitivity of the method.

Résumé - Mesure de la dégradation de l'oxytétracycline présente dans le miel par fluorescence et chromatographie liquide. Dans de nombreux pays la législation n'autorise pas la présence de résidus d'oxytétracycline (OTC), un antibiotique utilisé contre les loques européenne et américaine, dans le miel commercialisé. Au niveau, ou tout près, de la limite inférieure de détection par fluorescence, nous avons trouvé que des sources de nectar imprévues pouvaient conduire à des résultats faussement positifs. Afin d'accroître la sensibilité et la fiabilité de la détection des traces d'OTC dans des échantillons de miel, 
une méthode rapide isocratique par HPLC a été mise au point. Elle utilise une colonne polystyrène- $60 \%$ divinylbenzène $15 \mathrm{~cm}$ $x 4,6 \mathrm{~cm}$ (Polymer Labs, PLRP-S). Le miel est dilué à l'acide chlorhydrique $(0,1 \mathrm{~N})$ dans la proportion $1: 4$ et une quantité de $200 \mu \mathrm{l}$ de solution de miel est injectée. L'utilité de la méthode a été montrée en traitant des ruches expérimentales à l'OTC et en analysant le miel stocké par les butineuses. L'analyse par fluorescence comme la méthode HPLC se sont montrées capables de déterminer la stabilité de l'OTC dans des solutions aqueuses et dans du miel conservé à différentes températures. Cette nouvelle méthode HPLC permet de déterminer en 15 min dans des échantillons de miel des quantités d'OTC comprises entre 0,5 et $50 \mathrm{ppm}$.

\section{miel / résidu / antibiotique / HPLC / fluo-} rescence

\section{Zusammenfassung - Abbau von Oxy-} tetrazyklin im Honig bestimmt durch Floreszenz- und Flüssig- Chromatographie-Analysen. Die staatlichen Vorschriften verbieten in vielen Ländern Rückstände von Oxytetrazyklin (OTC; ein Antibiotikum; Anm d Red) im vermakteten Honigen. Auf oder in Nähe der Untergrenze der Nachweisbarkeit durch Fluoreszenzanalyse haben wir festgestellt, daß es durch unvorhergesehene Nektarquellen zu flaschen positiven Werten kommen kann. Um die höchste Empfindlichkeit mit erhöhter Verläßlichkeit bei der Entdeckung von OTC-Spuren in Honigproben zu verbinden, wurde eine HPLC-Schnellmethode entwickelt, wobei eine Polystyren-60\% Divinylbenzen-Säule von Polymer Labs, PLRP-S, benutzt wird. Honig wird im Verhältnis $1: 4$ mit $0.1 \mathrm{~N}$ Salzsäure verdünnt und ein $200 \mu$ Aliquot der gelösten Honigprobe injiziert.
Die Brauchbarkeit der Methode wurde dadurch nachgewiesen, daß Versuchsvölker mit OTC behandelt und die eingelagerten Honige analysiert wurden. Sowohl die Fluoreszenz-Analyse wie die HPLCMethode erwiesen sich als geeignet, die Stabilität von Oxytetrazyklin in wäßrigen Lösungen und in Honigen, die bei verschiedenen Temperaturen gelagert waren, nachzuweisen. Mit der hier beschriebenen neuen HPLC-Methode können Mengen zwischen 0.5 und $50 \mathrm{ppm}$ OTC in Honigproben innerhalb 15 Minuten bestimmt werden.

\section{Honig / Rückstand / Antibiotikum / HPLC / Fluoreszenz}

\section{REFERENCES}

Argauer RJ (1986) Antibiotics in beekeeping. In: Agricultural Uses of Antibiotics (Moats WA, ed) Am Chem Soc Washington, ACS Symp Ser 320, 35-48

Ashworth RB (1985) Liquid chromatographic assay of tetracyclines in tissues of foodproducing animals. $J$ Assoc Off Anal Chem $68,1013-1018$

Corner J, Gochnauer TA (1971) The persistence of tetracycline activity in medicated syrup stored by wintering honeybee colonies. J Apic Res 10, 67-71

Gilliam M, Argauer RJ (1981) Oxytetracycline residues in surplus honey, brood nest honey, and larvae after medication of colonies of honey bees, Apis mellifera, with antibiotic extender patties, sugar dust, and syrup sprays. Environ Entomol 10, 479-482

Gochnauer TA, Bland SE (1974) Persistence of oxytetracycline activity in medicated syrup stored in honeybee colonies in late spring. J Apic Res 13, 153-159

Ikai Y, Oka H, Kawamura N, Yamada M (1987) XIII. Systematic simultaneous analysis of residual tetracyclines in animal tissues using thin-layer and high-performance liquid chromatography. J Chromatogr $411,313-323$ 
Juergens U (1981) High-pressure liquid chromatographic analysis of residues of drugs in honey. I. Tetracycline. $Z$ Lebensm Unters Forsch 173, 356-358

Knox JH, Jurand $J$ (1979) Mechanism of reversed-phase separation of tetracyclines by high-performance liquid chromatography. $J$ Chromatogr 186, 763-782

Oka $\mathrm{H}$, Ikai $Y$, Kawamura N, Uno K, Yamada $M$, Harada $K$, Uchiyama $M$, Uchiyama $M$, Asukabe H, Mori Y, Suzuki M (1987) IX. A simple method for residual tetracycline analysis in honey using a tandem cartridge clean-up system. J Chromatogr 389, 417-426

Moats WA (1986a) Agricultural Uses of Antibiotics. Chem Soc Washington, ACS Symp Ser 320, pp 184
Moats WA (1986b) Determination of tetracycline antibiotics in tissues and blood serum of cattle and swine by high performance liquid chromatography. J Chromatogr 358, 253-259

Rousseau M, Tabarly O (1962) L'emploi des antibiotiques en apiculture : leur présence dans le miel. Bull Apic Doc Sci Tech Inf 5, 155-176

Sporns P, Kwan S, Roth LA (1986) HPLC analysis of oxytetracycline residues in honey. J Food Prot 49, 383-388

Takeba K, Kanzaki M, Murakami F, Matsumoto $M$ (1984) Simplified analytical method for tetracycline residues in honey by high performance liquid chromatography. Kenkyu Nenpo-Tokyo-toritsu Eisei Kenkyusho 35: 187191 (in Japanese); (Apic Abstr 1986, p 164) 